\title{
УДОСКОНАЛЕННЯ ЗВІТУ ПРО РУХ ГРОШОВИХ КОШТІВ У КОНТЕКСТІ ЄВРОПЕЙСЬКОЇ ІНТЕГРАЦІЇ
}

\begin{abstract}
У статті проаналізовано чинні нормативні документи, якими регламентовано формування Звіту про рух грошових коштів в Україні, досліджено теоретико-методичні підходи до сутності Звіту про рух грошових коштів. Визначено недоліки складання існуючих форм звітності на основі використання чинних нормативних документів та концепцій вчених-економістів щодо формування звітності із руху грошових коштів. Запропоновані шляхи покращення процесу формування Звіту про рух грошових коштів. Дослідження існуючих підходів до заповнення у звіті про рух грошових коштів інформації про зміну оборотних активів та поточних зобов'язань підприємства дозволило запропонувати використання робочих таблиць для заповнення цих статей, що дозволить спростити процес формування показників та підсилить взаємозв'язок звіту про рух грошових коштів з іншими формами фінансової звітності. Така процедура позитивно сприймається користувачами фінансової звітності та контролюючими органами.
\end{abstract}

Ключові слова: грошові кошти, фінансова звітність, Звіт про рух грошових коштів, прямий метод, непрямий метод.

MATUH S., LOPATOVSKYI V.

Khmelnytskyi National University

Improving a cash flow statement in the context of european integration

This article investigates the theoretical and methodological approaches of the nature of the statement of cash flows. The subject of the article is relevant, since filling in the cash flow statement today causes difficulties for practicing accountants of domestic enterprises. Identified disadvantages of the compilation report form based on the use of regulations and concepts of economists in this topic. Offered the ways of improvement the process of forming of cash flow Statement. The study of existing approaches to filling in the cash flow statement of information on changes in current assets and current liabilities of the company has allowed us to propose the use of worksheets to fill these articles, which will simplify the process of formation of indicators and strengthen the relationship of the statement of cash flows with other forms of financial reporting. Such a procedure is positively perceived by users of financial statements and supervisors. The article describes in detail the use of the direct and indirect method used to fill the cash flow statement in Ukraine and abroad. The authors of the article propose to improve the procedure for filling in the cash flow statement by introducing additional work tables, which provide information on changes in current assets and changes in current liabilities of the enterprise. The results of a scientific article can be used by accountants of domestic enterprises in preparing the indicators of the cash flow statement; users of financial reporting in the process of analysis of indicators in order to make managerial decisions; employees of the controlling bodies during conducting a check on indicators of various forms of financial reporting; scientists in the process of further research to improve the methodology for filling in the statement of cash flow. Keywords: cash, cash flow, financial reporting, legal regulation of accounting of funds, direct method, indirect method, additional articles.

Вступ. В ринковій економіці розвиток економічних відносин значною мірою визначається наявністю та спроможністю суб'єктів підприємницької діяльності забезпечувати стабільне і достатнє надходження та ефективне використання грошових коштів. Ефективне функціонування суб'єктів підприємницької діяльності зумовлюється станом їх грошових потоків, які є відображенням комплексу економічних процесів, що відбуваються між підприємством та його контрагентами. Ефективність цього функціонування значною мірою залежить від якості іiі інформаційної бази. Відповідно до національних положень (стандартів) бухгалтерського обліку вітчизняні підприємства у складі річної фінансової звітності повинні подавати Звіт про рух грошових коштів, який пояснює шляхи надходження і вибуття коштів, об'єднаних за окремими ознаками у розрізі основних видів господарської діяльності. Його структура та зміст є предметом критичного обговорення та потребують удосконалення у контексті інтеграції до європейського співтовариства.

В спеціалізованих бухгалтерських періодичних виданнях щорічно друкуються рекомендації із заповнення форм фінансової звітності, в тому числі й Звіту про рух грошових коштів. Однак недостатньо повно висвітлюються найбільш складні та трудомісткі статті складання Звіту, зокрема пов'язані 3 операційною діяльністю. У цьому контексті особливої уваги потребує визначення показників зменшення (збільшення) оборотних активів та збільшення (зменшення) поточних зобов'язань. Складність розрахунку окремих показників цього звіту зумовлює потребу в докладному аналізі та поясненнях щодо їх формування.

Опубліковані з проблематики оцінки руху грошових коштів теоретичні концепції, методичні підходи та практичні розробки переконливо доводять, що для підвищення ефективності управління фінансово-господарською діяльністю підприємства потрібно оцінювати прибутковість грошових потоків усіх видів діяльності суб'єкта господарювання. Однак цим питанням при управлінні фінансовогосподарською діяльністю підприємства на сьогоднішній час не приділяється достатньої уваги. Недостатня 
вивченість цих питань, а також їх практична значущість як для бухгалтерів, так і для користувачів фінансової звітності, підкреслює своєчасність і актуальність обраної теми.

Метою статті є вдосконалення методики складання Звіту про рух грошових коштів шляхом розробки методичних положень щодо заповнення найскладніших статей цього звіту.

Виклад основного матеріалу дослідження. Звіт про рух грошових коштів введено до складу фінансової звітності з метою найбільш повного опису діяльності суб’єкта підприємницької діяльності. Користувачами цієї звітності є власники, інвестори, що здійснюють вкладення у бізнес та розраховують на їх повернення та регулярне отримання дивідендів; кредитори, які надають підприємству фінансові та комерційні кредити та розраховують на їх повернення, а також на регулярне отримання відсотків за цими кредитами.

У процесі подальшої євроінтеграції економіки України все більше вітчизняних суб'єктів господарювання при складанні власної фінансової звітності орієнтуються на вимоги міжнародних стандартів фінансової звітності. На сьогодні вимогу складання фінансової звітності за міжнародними стандартами мають «підприємства, що становлять суспільний інтерес, публічні акціонерні товариства, суб'єкти господарювання, які здійснюють діяльність у видобувних галузях, а також підприємства, які провадять господарську діяльність за видами, перелік яких визначається Кабінетом Міністрів України, складають фінансову звітність та консолідовану фінансову звітність за міжнародними стандартами» [1]. Усі решта суб'єктів господарювання можуть самостійно визначають доцільність застосування міжнародних стандартів для складання власної фінансової звітності, своєчасно інформуючи про це територіальні органи статистики.

Серед усіх наявних форм фінансової звітності, які на сьогодні є необхідними для заповнення підприємствами України, крім тих, що належать до категорії малих, лише одна форма звітності має можливість вибору - складання ії за прямим або непрямим методом. 3 одного боку, це дозволяє обліковому персоналу (як правило, безпосередньо головному бухгалтеру, який відповідає за складання фінансової звітності) обрати один із цих варіантів відповідно до специфіки та обсягів діяльності свого підприємства, а також враховуючи власний досвід щодо використання цих методів у минулому.

Можливість складання звіту про рух грошових коштів одним із цих двох методів ставить під сумнів проведення зіставності показників різних підприємств або навіть одного підприємства, якщо його керівництво протягом досліджуваного періоду змінювало метод заповнення звіту про рух грошових коштів. Це суперечить вимогам п. 4 розділу III Національного положення (стандарту) бухгалтерського обліку 1 «Загальні вимоги до фінансової звітності», за яким фінансова звітність повинна надавати можливість користувачам порівнювати:

- фінансові звіти підприємства за різні періоди;

- фінансові звіти різних підприємств [2].

При цьому слід розуміти, що можливість заповнення звіту про рух грошових коштів за прямим та непрямим методом наявна як у національних положеннях (стандартах) бухгалтерського обліку, так і у міжнародних стандартах фінансової звітності.

У вітчизняній практиці тривалий час для заповнення звіту про рух грошових використовувався лише один із двох методів. Довгий час на законодавчому рівні був закріплений непрямий метод заповнення цього звіту, який негативно сприймався бухгалтерами невеликих підприємств. Пізніше нормативно було введено прямий метод заповнення звіту про рух грошових коштів. При цьому значні складнощі при заповненні мали бухгалтери великих підприємств зі значними обсягами даних грошових операцій.

Протягом останніх п’яти років обидва методи є вільними для самостійного вибору керівництва підприємствами. Не слід забувати, що непрямий метод застосовується лише до показників першого розділу звіту, де розкривається інформація про рух грошових коштів у розрізі операційної діяльності, натомість набір статей другого та третього розділів (рух коштів від інвестиційної та фінансової діяльності відповідно) та методика їх заповнення $є$ незмінною і відбувається із використанням виключно прямого методу заповнення.

У більшості випадків непрямий метод заповнення звіту про рух грошових коштів обирається бухгалтерами великих компаній, у яких за звітний рік відбувається величезна кількість операцій, пов'язана iз рухом грошових коштів. Натомість прямий метод більш звичний для невеликих підприємств, у яких річний масив грошових операцій є невеликим і досить легко може бути проаналізований та згрупований за видами діяльності підприємства (операційна, інвестиційна та фінансова).

При цьому хочеться зазначити, що у кожного із цих методів є свої переваги та недоліки [6]. Непрямий метод дозволяє легше порівняти показники звіту про рух грошових коштів із показниками інших форм річної фінансової звітності підприємства, але не дає змоги побачити генерацію грошових потоків (надходжень та витрачань грошових коштів), що ускладнює можливість аналітичного використання показників звіту у процесі планування грошових потоків на наступні періоди. Натомість прямий метод чітко розмежовує грошові потоки за основними операціями у розрізі трьох видів діяльності підприємства, але ускладнює процес взаємозвірки показників цього звіту, оскільки набір показників звіту про рух грошових коштів, складеного за прямим методом, не корелює з показниками інших форм фінансової звітності.

Слід зазначити, що в міжнародній практиці обліку при складанні Звіту про рух грошових коштів перевага надається непрямому методу. Згідно з опублікованими даними непрямому методу складання звіту 
віддають перевагу 97,5\% компаній у США. Британський стандарт FRS-1 вважає, що звіт, складений непрямим методом, більше влаштовує тих користувачів, яких цікавить якість доходів компанії (з урахуванням структури негрошових статей, динаміки змін залишків тощо). Перевагу прямому методу віддадуть користувачі, орієнтовані тільки на кількісні характеристики [4, с. 625].

Зважаючи на складність заповнення цього звіту бухгалтерами, труднощі при переході на один із наявних методів та важливе значення звіту для користувачів інформації з метою прийняття правильних управлінських рішень, варто погодитися на доцільність наявності самостійного вибору підприємствами одного із двох методів його заповнення. Але при цьому не слід забувати про ті складнощі, які виникають у бухгалтерів, коли вони обирають один із цих методів.

Якщо оцінювати непрямий метод заповнення звіту про рух грошових коштів, то найбільшою проблемою у ньому є необхідність складання так званих робочих таблиць при заповненні показників щодо змін за звітний період оборотних активів підприємства (стаття 3550 «Зменшення (збільшення) оборотних активів» та його поточних зобов'язань (стаття 3560 «Збільшення (зменшення) поточних зобов'язань»). На жаль, в методичних рекомендаціях щодо заповнення форм фінансової звітності [3] відсутня згадка про такий допоміжний інструмент при заповненні звіту про рух грошових коштів. Зрозуміло, що відсутні при цьому їх шаблон та методика заповнення. Враховуючи набір показників у активі бухгалтерського балансу та інформацію про те, які показники не включаються при заповненні статті 3550 «Зменшення (збільшення) оборотних активів» (таблиця 1), нами запропоновано у вигляді додатку до звіту про рух грошових коштів розроблений макет робочої таблиці, яка враховує зміни оборотних активів підприємства за звітний період (табл. 2).

Таблиця 1

\section{Інформація, що не враховусться при заповненні статті 3550} «Зменшення (збільшення) оборотних активів»

\begin{tabular}{|c|l|}
\hline № 3/п & \multicolumn{1}{c|}{ Назва показника } \\
\hline 1 & Стаття балансу «Гроші кошти та їх еквіваленти» \\
\hline 2 & Стаття балансу «Поточні фінансові інвестиції» \\
\hline 3 & Інші статі неопераційних оборотних активів \\
\hline 4 & $\begin{array}{l}\text { Зміни в складі оборотних активів, які є наслідком негрошових операцій інвестиційної діяльності (обмін на необоротні } \\
\text { активи, фінансові інвестиції тощо) }\end{array}$ \\
\hline 5 & $\begin{array}{l}\text { Зміни в складі оборотних активів, які є наслідком негрошових операцій фінансової діяльності (виплата дивідендів або } \\
\text { погашення зобов'язань з фінансової оренди виробничими запасами, продукцією, товарами тощо, негрошові внески до } \\
\text { статутного капіталу, включення фінансових витрат до собівартості продукції тощо) }\end{array}$ \\
\hline 6 & Зміни в складі оборотних активів, які є наслідком виправлення помилок минулих років \\
\hline 7 & $\begin{array}{l}\text { Зміна дебіторської заборгованості поточного податку на прибуток і зменшення дебіторської заборгованості за іншими } \\
\text { платежами до бюджету внаслідок зарахування кредиторської заборгованості за поточним податком на прибуток }\end{array}$ \\
\hline 8 & $\begin{array}{l}\text { Зміни в складі дебіторської заборгованості за розрахунками з податку на додану вартість, які є наслідком інвестиційної } \\
\text { діяльності }\end{array}$ \\
\hline 9 & $\begin{array}{l}\text { Зменшення статей оборотних активів внаслідок переведення оборотних активів до складу групи вибуття, збільшення } \\
\text { дебіторської заборгованості внаслідок відображення операцій з реалізації інвестиційної нерухомості, необоротних активів, } \\
\text { утримуваних для продажу, та групи вибуття і зменшення зазначеної дебіторської заборгованості внаслідок її погашення }\end{array}$ \\
\hline
\end{tabular}

Робоча таблиця щодо визначення зміни оборотних активів для заповнення статті 3550

Таблиця 2 «Зменшення (збілышення) оборотних активів»

\begin{tabular}{|c|c|c|c|c|}
\hline \multirow[b]{2}{*}{ Назва показника балансу } & \multirow[b]{2}{*}{$\begin{array}{l}\text { Значення на } \\
\text { початок } \\
\text { періоду }\end{array}$} & \multirow[b]{2}{*}{$\begin{array}{l}\text { Значення на } \\
\text { кінець періоду }\end{array}$} & \multicolumn{2}{|c|}{ Відображення у Звіті про рух грошових коштів } \\
\hline & & & $\begin{array}{l}\text { Якщо значення показника на } \\
\text { кінець періоду більше, ніж } \\
\text { значення на кінець періоду }\end{array}$ & $\begin{array}{l}\text { Якщо значення показника } \\
\text { на початок періоду більше, } \\
\text { ніж значення на початок } \\
\text { періоду }\end{array}$ \\
\hline Запаси & $\begin{array}{l}\text { гр. } 3 \text { ряд. } 1100 \\
\text { ф.№1 }\end{array}$ & $\begin{array}{l}\text { гр. } 4 \text { ряд. } 1100 \\
\text { ф.№1 }\end{array}$ & $\begin{array}{l}\text { Додатна різниця (гр. } 4 \text { - гр. 3) } \\
\text { переноситься у гр. } 4 \text { ряд. } 3551 *\end{array}$ & $\begin{array}{l}\text { Додатна різниця (гр. } 3 \text { - гр. 4) } \\
\text { переноситься у гр. } 3 \text { ряд. } 3551 *\end{array}$ \\
\hline Поточні біологічні активи & $\begin{array}{l}\text { гр. } 3 \text { ряд. } 1110 \\
\text { ф.№1 }\end{array}$ & $\begin{array}{l}\text { гр. } 4 \text { ряд. } 1110 \\
\text { ф.№1 }\end{array}$ & $\begin{array}{l}\text { Додатна різниця (гр. } 4 \text { - гр. 3) } \\
\text { переноситься у гр. } 4 \text { ряд. } 3552 *\end{array}$ & $\begin{array}{l}\text { Додатна різниця (гр. } 3 \text { - гр. 4) } \\
\text { переноситься у гр. } 3 \text { ряд. } 3552 *\end{array}$ \\
\hline $\begin{array}{l}\text { Дебіторська заборгованість } \\
\text { за продукцію, товари, } \\
\text { роботи, послуги }\end{array}$ & $\begin{array}{l}\text { гр. } 3 \text { ряд. } 1155 \\
\text { ф.№1 }\end{array}$ & $\begin{array}{l}\text { гр. } 4 \text { ряд. } 1155 \\
\text { ф.№1 }\end{array}$ & $\begin{array}{l}\text { Додатна різниця гр. } 4 \text { - } \\
\text { гр. 3) переноситься у гр. } 4 \text { ряд. } \\
3553^{*}\end{array}$ & $\begin{array}{l}\text { Додатна різниця (гр. } 3 \text { - гр. 4) } \\
\text { переноситься у у гр. } 3 \text { ряд. } \\
3553^{*}\end{array}$ \\
\hline $\begin{array}{l}\text { Інша поточна дебіторська } \\
\text { заборгованість }\end{array}$ & $\begin{array}{l}\text { гр. } 3 \text { ряд. } 1155 \\
\text { ф.№1 }\end{array}$ & $\begin{array}{l}\text { гр. } 4 \text { ряд. } 1155 \\
\text { ф.№1 }\end{array}$ & $\begin{array}{l}\text { Додатна різниця гр. } 4 \text { - } \\
\text { гр. 3) переноситься у гр. } 4 \text { ряд. } \\
3554 *\end{array}$ & $\begin{array}{l}\text { Додатна різниця (гр. } 3 \text { - гр. 4) } \\
\text { переноситься } \text { у } \quad \text { гр. } 3 \text { ряд. } \\
\text { 3554* }\end{array}$ \\
\hline майбутніх & $\begin{array}{l}\text { гр. } 3 \text { ряд. } 1170 \\
\text { ф.№1 }\end{array}$ & $\begin{array}{l}\text { гр. } 4 \text { ряд. } 1170 \\
\text { ф.№1 }\end{array}$ & $\begin{array}{l}\text { Додатна різниця гр. } 4 \text { - } \\
\text { гр. 3) переноситься у гр. } 4 \text { ряд. } \\
3556^{*}\end{array}$ & $\begin{array}{l}\text { Додатна різниця (гр. } 3 \text { - гр. 4) } \\
\text { переноситься у у гр. } 3 \text { ряд. } \\
3556^{*}\end{array}$ \\
\hline Інші оборотні активи & $\begin{array}{l}\text { гр. } 3 \text { ряд. } 1190 \\
\text { ф.№1 }\end{array}$ & $\begin{array}{l}\text { гр. } 4 \text { ряд. } 1190 \\
\text { ф.№1 }\end{array}$ & $\begin{array}{l}\text { Додатна різниця гр. } 4 \text { - } \\
\text { гр. 3) переноситься у гр. } 4 \text { ряд. } \\
3557^{*}\end{array}$ & $\begin{array}{l}\text { Додатна різниця (гр. } 3 \text { - гр. 4) } \\
\text { переноситься } \\
3557 *\end{array}$ \\
\hline Всього оборотних активів & & & $\begin{array}{l}\text { Додатна різниця гр. } 4 \text { - } \\
\text { гр. 3) переноситься у гр. } 4 \text { ряд. } \\
3550\end{array}$ & $\begin{array}{l}\text { Додатна різниця (гр. } 3 \text { - гр. 4) } \\
\text { переноситься у гр. } 3 \text { ряд. } 3550\end{array}$ \\
\hline
\end{tabular}


Також слід заповнювати подібну таблицю при розрахунку показника у статті 3560 «Збільшення (зменшення) поточних зобов'язань». У разі визначення суми збільшення (зменшення) поточних зобов'язань за звітний період не враховується зменшення суми зобов'язань: з поточного податку на прибуток унаслідок його сплати та враховується зменшення суми зобов'язання з поточного податку на прибуток внаслідок його списання та визнання доходу (внаслідок того, що цей податок відображається окремою статтею у звіті); 3 ПДВ, що виникають внаслідок інвестиційної діяльності. Форма такої робочої таблиці наведена у таблиці 3.

Робоча таблиця щодо визначення зміни поточних зобов'язань для заповнення статті 3560

Таблиця 3 «Збільшення (зменшення) поточних зобов'язань»

\begin{tabular}{|c|c|c|c|c|}
\hline \multirow[b]{2}{*}{ Назва показника балансу } & \multirow[b]{2}{*}{$\begin{array}{l}\text { Значення на } \\
\text { початок } \\
\text { періоду }\end{array}$} & \multirow[b]{2}{*}{$\begin{array}{l}\text { Значення на } \\
\text { кінець } \\
\text { періоду }\end{array}$} & \multicolumn{2}{|c|}{ Відображення у Звіті про рух грошових коштів } \\
\hline & & & $\begin{array}{l}\text { Якщо значення показника на } \\
\text { кінець періоду більше, ніж } \\
\text { значення на початок періоду }\end{array}$ & $\begin{array}{l}\text { Якщо значення показника } \\
\text { на початок періоду більше, } \\
\text { ніж значення на кінець } \\
\text { періоду }\end{array}$ \\
\hline $\begin{array}{l}\text { Поточна кредиторська } \\
\text { заборгованість за товари, } \\
\text { роботи, послуги }\end{array}$ & $\begin{array}{l}\text { гр. } 3 \text { ряд. } 1610 \\
\text { ф.№1 }\end{array}$ & $\begin{array}{l}\text { гр. } 4 \text { ряд. } 1610 \\
\text { ф.№1 }\end{array}$ & $\begin{array}{l}\text { Додатна різниця (гр. } 4 \text { - гр. 3) } \\
\text { переноситься у гр.3 ряд. } 3561 *\end{array}$ & $\begin{array}{l}\text { Додатна різниця (гр. } 3 \text { - гр. 4) } \\
\text { переноситься у гр. } 4 \text { ряд. } \\
3561 *\end{array}$ \\
\hline $\begin{array}{l}\text { Поточна кредиторська } \\
\text { заборгованість за } \\
\text { розрахунками з бюджетом }\end{array}$ & $\begin{array}{l}\text { гр. } 3 \text { ряд. } 1620 \\
\text { ф.№1 }\end{array}$ & $\begin{array}{l}\text { гр. } 4 \text { ряд. } 1620 \\
\text { ф.№1 }\end{array}$ & $\begin{array}{l}\text { Додатна різниця (гр. } 4 \text { - гр. 3) } \\
\text { переноситься у гр.3 ряд. } 3562 *\end{array}$ & $\begin{array}{l}\text { Додатна різниця (гр. } 3 \text { - гр. 4) } \\
\text { переноситься у гр. } 4 \text { ряд. } \\
3562 *\end{array}$ \\
\hline $\begin{array}{lr}\text { Поточна } & \text { кредиторська } \\
\text { заборгованість } & \text { за } \\
\text { розрахунками } \\
\text { страхування }\end{array}$ & $\begin{array}{l}\text { гр. } 3 \text { ряд. } 1625 \\
\text { ф.№1 }\end{array}$ & $\begin{array}{l}\text { гр. } 4 \text { ряд. } 1625 \\
\text { ф.№1 }\end{array}$ & $\begin{array}{l}\text { Додатна різниця (гр. } 4 \text { - гр. 3) } \\
\text { переноситься у гр. } 3 \text { ряд. 3563* }\end{array}$ & $\begin{array}{l}\text { Додатна різниця (гр. } 3 \text { - гр. } 4) \\
\text { переноситься у гр. } 4 \text { ряд. } \\
3563^{*}\end{array}$ \\
\hline $\begin{array}{lr}\text { Поточна } & \text { кредиторська } \\
\text { заборгованість } \\
\text { розрахунками } \\
\text { праці }\end{array}$ & $\begin{array}{l}\text { гр. } 3 \text { ряд. } 1630 \\
\text { ф.№1 }\end{array}$ & $\begin{array}{l}\text { гр. } 4 \text { ряд. } 1630 \\
\text { ф.№1 }\end{array}$ & $\begin{array}{l}\text { Додатна різниця (гр. } 4 \text { - гр. 3) } \\
\text { переноситься у гр. } 3 \text { ряд. 3564* }\end{array}$ & $\begin{array}{l}\text { Додатна різниця (гр. } 3 \text { - гр. } 4) \\
\text { переноситься } \quad \text { у гр. } 4 \text { ряд. } \\
3564 *\end{array}$ \\
\hline Доходи майбутніх періодів & $\begin{array}{l}\text { гр. } 3 \text { ряд. } 1665 \\
\text { ф.№1 }\end{array}$ & $\begin{array}{l}\text { гр. } 4 \text { ряд. } 1665 \\
\text { ф.№1 }\end{array}$ & $\begin{array}{l}\text { Додатна різниця (гр. } 4 \text { - гр. 3) } \\
\text { переноситься у гр. } 3 \text { ряд. 3566* }\end{array}$ & $\begin{array}{l}\text { Додатна різниця (гр. } 3 \text { - гр. 4) } \\
\text { переноситься у гр. } 4 \text { ряд. } \\
3566^{*}\end{array}$ \\
\hline Інші поточні зобов'язання & $\begin{array}{l}\text { гр. } 3 \text { ряд. } 1690 \\
\text { ф.№1 }\end{array}$ & $\begin{array}{l}\text { гр. } 4 \text { ряд. } 1690 \\
\text { ф.№1 }\end{array}$ & $\begin{array}{l}\text { Додатна різниця (гр. } 4 \text { - гр. 3) } \\
\text { переноситься у гр. } 3 \text { ряд. } 3567 *\end{array}$ & $\begin{array}{l}\text { Додатна різниця (гр. } 3 \text { - гр. 4) } \\
\text { переноситься у гр. } 4 \text { ряд. } \\
3567 *\end{array}$ \\
\hline Всього зобов'язань & & & $\begin{array}{l}\text { Додатна різниця (гр. } 4 \text { - гр. 3) } \\
\text { переноситься у гр. } 3 \text { ряд. 3560* }\end{array}$ & $\begin{array}{l}\text { Додатна різниця (гр. } 3 \text { - гр. 4) } \\
\text { переноситься у гр. } 4 \text { ряд. } \\
3560 *\end{array}$ \\
\hline
\end{tabular}

У табл. 2 та 3 включаються дані за звітний період, окрім зміни у результаті негрошових операцій інвестиційної та фінансової діяльності, а також виправлення помилок минулих років. Такі таблиці допоможуть бухгалтерам підприємств легше зорієнтуватися під час заповнення найбільш складних рядків звіту про рух грошових коштів за непрямим методом.

Заповнення рядків «Зменшення (збільшення) оборотних активів», «Збільшення (зменшення) поточних зобов'язань» також вимагає виділення зі складу дебіторської і кредиторської заборгованостей тієї частини, що стосується виключно операційної діяльності та має бути включена саме до цих рядків. Таким чином виникає необхідність ведення докладного аналітичного обліку дебіторської та кредиторської заборгованостей підприємства, що виникли в результаті операційної, інвестиційної або фінансової діяльності з виділенням тієі частини заборгованості, яка була погашена в результаті негрошових операцій, оскільки у вище зазначених статтях до уваги буде братися лише та частина дебіторської та кредиторської заборгованостей, яка виникла у результаті операційної діяльності та була погашена грошовими коштами.

Наявність такої інформації дозволить здійснювати стратегічне та оперативне планування руху грошових коштів 3 метою попередження ситуації, коли прибуткове підприємство є неспроможним розрахуватись за своїми зобов'язаннями, зробити висновки щодо організованості управління грошовими потоками (чи в будь-який момент у розпорядженні підприємства є достатня кількість грошових коштів).

Висновки. Вивчення поглядів вітчизняних та зарубіжних вчених щодо складання Звіту про рух грошових коштів дає можливість зробити висновок, що непрямий метод його заповнення є більш вживаним, оскільки він побудований на застосуванні уже наявних показників Балансу, Звіту про фінансові результати та регістрів бухгалтерського обліку. 3 точки зору оцінки аналітичності отримана інформація, розрахована непрямим методом, повніше відображає співвідношення руху грошових засобів і фінансово-господарської діяльності підприємства. Для підвищення аналітичності інформації пропонується додати до звіту про рух грошових коштів, який заповнюється непрямим методом, робочі таблиці, які детально відображають процедуру заповнення найбільш складних статей цього звіту (щодо зміни оборотних активів та поточних зобов’язань). Такі таблиці значно збільшать можливості взаємозвірки показників різних форм річної фінансової звітності підприємств. 


\section{Література}

1. Про бухгалтерський облік та фінансову звітність в Україні [Електронний ресурс] : закон України від 16.07.99 р. № 996-XIV із наступними змінами та доп. - Режим доступу : http://zakon2.rada.gov.ua/laws/show/996-14

2. Загальні вимоги до фінансової звітності [Електронний ресурс] : національне положення (стандарт) бухгалтерського обліку 1 : затверджене наказом Міністерства фінансів України від 07.02.2013 р. № 73 із наступними змінами та доп. - Режим доступу : http://zakon3.rada.gov.ua/laws/show/z0336-13

3. Методичні рекомендації щодо заповнення форм фінансової звітності [Електронний ресурс] : затверджені Наказом Мінфіну України від 28.03.2013 р. № 433. - Режим доступу : http://zakon.rada.gov.ua/rada/show/v0433201-13/conv

4. Elliott Barry, Elliott Jamie. Financial Accounting \& Reporting. Prentice Hall, 2010.

5. Атамас П.Й. Методичні проблеми складання Звіту про рух грошових коштів та шляхи їх вирішення / П.Й. Атамас, О.П. Атамас // Європейський вектор економічного розвитку : збірник наукових праць. - 2013. - № 1 (14). - С. 3-11.

6. Лопатовський В.Г. Особливості заповнення Звіту про рух грошових коштів підприємств за національними стандартами бухгалтерського обліку / В.Г. Лопатовський, О.І. Русин // Вісник Хмельницького національного університету. Економічні науки. 2016. - № 2. T. 2. - C. 130-134.

\section{References}

1. Pro bukhhalterskyi oblik ta finansovu zvitnist v Ukraini [Elektronnyi resurs] : zakon Ukrainy vid 16.07.99 r. № 996-XIV iz nastupnymy zminamy ta dop. - Rezhym dostupu : http://zakon2.rada.gov.ua/laws/show/996-14

2. Zahalni vymohy do finansovoi zvitnosti [Elektronnyi resurs] : natsionalne polozhennia (standart) bukhhalterskoho obliku 1 : zatverdzhene nakazom Ministerstva finansiv Ukrainy vid 07.02.2013 r. № 73 iz nastupnymy zminamy ta dop. - Rezhym dostupu : http://zakon3.rada.gov.ua/laws/show/z0336-13

3. Metodychni rekomendatsii shchodo zapovnennia form finansovoi zvitnosti [Elektronnyi resurs] : zatverdzheni Nakazom Minfinu Ukrainy vid 28.03.2013 r. № 433. - Rezhym dostupu : http://zakon.rada.gov.ua/rada/show/v0433201-13/conv

4. Elliott Barry, Elliott Jamie. Financial Accounting \& Reporting. Prentice Hall, 2010.

5. Atamas P.I. Metodychni problemy skladannia Zvitu pro rukh hroshovykh koshtiv ta shliakhy yikh vyrishennia / P.I. Atamas, O.P. Atamas // Yevropeiskyi vektor ekonomichnoho rozvytku : zbirnyk naukovykh prats. - 2013. - № 1 (14). - S. 3-11.

6. Lopatovskyi V.H. Osoblyvosti zapovnennia Zvitu pro rukh hroshovykh koshtiv pidpryiemstv za natsionalnymy standartamy bukhhalterskoho obliku / V.H. Lopatovskyi, O.I. Rusyn // Herald of Khmelnytskyi National University. - 2016. - № 2. T. 2. - S. $130-134$.

Рецензія / Peer review : 31.10.2018 Надрукована / Printed : 07.12.2018 Прорецензовано редакційною колегією 